\title{
Exploring and Studying the Shoreline Erosion Using Different Airborne Missions: An Example in Egypt North Coast
}

\author{
Hossam Eldin Mohammed Mohamed Elhanafy
}

\begin{abstract}
The climate changes cause sea level variation which varies spatial and temporal significantly, and it is now possible to reconstruct how sea level varied globally and regionally with time. The sea level rose faster than the global mean since 1950 is now a fact, and although it is not the only reason for shoreline erosion but it has a significant effects on the processes of shoreline erosion. The wave's actions are a dominant cause of shoreline erosion, even if affected by higher sea level rise rates. The research project reported in this paper investigates the shoreline erosion in the north coast of Egypt. Also the negative effects have been studied using new method. The developed methodology depends on using a stationary control measuring points instead of measuring the water depths near the shore line as previous researchers get used to apply in their studies.
\end{abstract}

Index Terms - Sea level rise, climate change, coastal erosion, north coast of Egypt.

\section{INTRODUCTION}

In coastal areas sea level rise and coastal erosion are considered the major concerns.

Development an accurate model able to represent accurately how different factors interact and cause coastal erosion is a great challenge. Even if such model have been developed its validation need a lot of data. Although development of such model has not been achieved, but several studied has been carried out to either investigate how certain factor affect the coastal erosion process, or study the rate of coastal erosion in a specified location due to its importance.

The fact that sea level rose faster than the global mean since 1950 have been studied [1], they extended their study to two additional atolls: Tetiaroa and Tupai in the Society islands. Both atolls remain stable on the whole from 1955 to 2001/02, however with significant differences in shoreline changes. [2] Suggest that wave's actions are a dominant cause of shoreline erosion, even if affected by higher sea level rise rates. In such cases, numerous joint analyses of shoreline changes and their potential causes may help to explain the relation between erosion and sea level rise.

The sea level raises and its actual consequences on coastal erosion are still rather unknown [3]. The sea level rise will favor erosion since waves will reach higher elevations in the upper beach [4]. Others [5] acknowledged that in addition to sea level variations, potential causes of shoreline mobility at decadal scales are hydrodynamics and meteorological factors (waves, current, tides, surges, winds, including during storms), the inherited geomorphology, present sediment budgets, bio sedimentary processes and human activities.

In contrast to the previously mentioned studied, [6] found in his research which is based on a global survey that the coastal erosion is related to local factors.

Several researches emphasize on when exploring the coastal erosion over a wide range of coastal sites, one has to consider the fact that sea level is not rising uniformly [7]-[9].

This due to three main reasons [10]-[12]:

Non uniform thermal expansion and salinity effects associated with ocean circulation changes.

Static effects due to the visco-elastic and elastic response of the solid Earth to past and present mass redistributions associated with last deglaciation and ongoing land ice melt.

Vertical land motions (e.g., subsidence or uplift due to tectonic and volcanic activity, subsidence due sediment loading, ground water pumping and oil \& gas extraction).

The previously mentioned reasons may either amplify or reduce the total relative sea level variation in a certain location.

The objectives of this paper are 1) illustrating the shore line changes along a specified region in the north coast of Egypt from comparison between areal air-born different missions; 2) illustrating an approach through examples on how from stationary ground control points the erosion criteria could be evaluated. 3) Validation of the recent mission with site investigation has been carried out.

Most of the previous researches applied the relationship between Sea level rise and coastal erosion in their studies. In the research project reported in this paper, the shoreline changes have been investigated from stationary ground points. These investigations have been carried out for three different missions; 1954, 2004, and 2012. The results for mission 2012 have been compared with site measurements to validate the data obtained from air-born mission, and then focusing on the analyses of shoreline changes representation in this region.

The paper starts with a brief description of the study area and its importance to Egypt Then, methods and results of the shoreline changes study are shown. Finally, the discussion attempts to find the potential causes of decadal shoreline changes in north coast of Egypt and to examine the significance of the results.

\section{THE STUDY AREA}

The study area is located in the Western-North coast of 
Egypt, 51-Km. East of Matruh City, as illustrated in Fig. 1.

This area is characterized by steep slope from the south to the north for a distance of three kilometers in average, in this zone the ground level drop from $150 \mathrm{~m}$ (A.S.L.) to $21 \mathrm{~m}$ (A.S.L.). Followed by light slope till the shore line at only distance of $1.5 \mathrm{~km}$ from the end of steep slope toward the north direction.

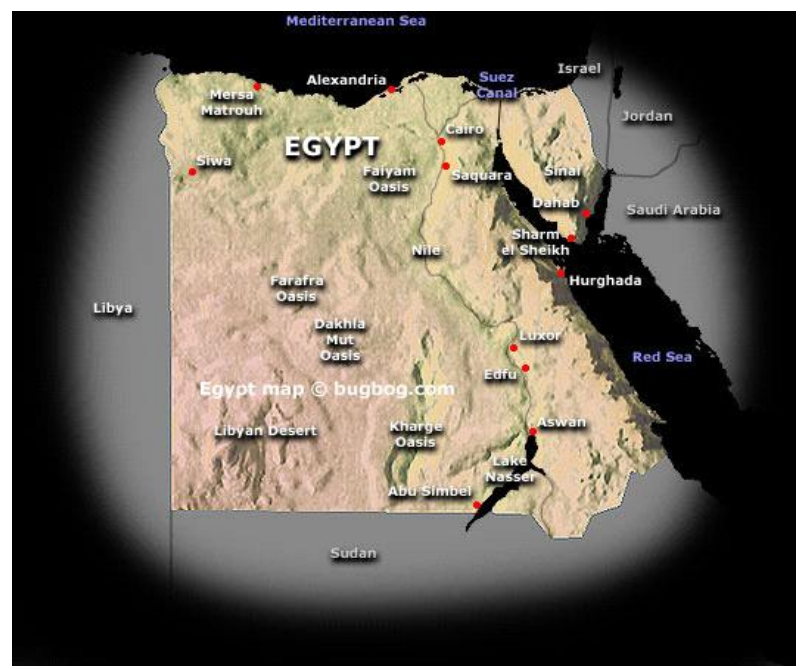

Fig. 1. Topographical map of Egypt.

The studied area is a small part of Matruh basin. Sedimentary rocks are of common occurrence, accounting for approximately $75 \%$ of the earth's exposed land surface, and about $87 \%$ of Arab Republic of Egypt. Sedimentary rocks are formed from sediment deposits when lithification, or consolidation of loose materials into solid rock, occurs. The drying process associated with exposure creates joints or cracks which are perpendicular to the original bedding planes and have no lateral movement.

There are two categories of sedimentary rock. The first category includes rocks that are clastic or fragmental, such as shales, sandstones, and conglomerates. The second category includes sedimentary rocks formed from chemical and organic sediments precipitated from solution. Rocks formed from these sediments include limestones, gypsums, and salt. Sandstone deposits are resistant to the forces of weathering. Joint patterns, having the appearance of rectangular blocks, can be easily observed since there is little soil cover. Cliffs may occur where sandstone overlie weaker sedimentary rocks, wind erosion and blowing sand may modify these vertical elements, rounding and carving them into streamlined shapes.

In Baghoush, the lack of residual soil cover allows the joints in sandstone to have maximum control over the drainage pattern. Thus, it is usually an angular dendritic pattern, medium to coarse in texture.

The Western North coast of Egypt is considered as arid region, it is characterized by less than 20 inches of annual rainfall but sometimes it exceeds this value. Precipitation is higher in winter months when temperature is relatively low. In such arid regions the landform are generally more rugged and without significant soil development over rock features. In these regions the lack of both precipitation and vegetation results in slower weathering, but when storms occur they tend to be severe, thereby causing rapid erosion of any materials that may have disintegrated. So the combined effect of ground covers erosion during flash floods, the Sea level rise.

Degradation in sea bed in front of the outlet station of flood ways will obviously cause changes in the shore line.

As many countries that are located on coastal regions Egypt concerned with the coastal development by establishing tourist villages and new cities along these areas. The government starts to develop the coastal region since 1980 's by constructing many of the tourist villages and new cities and also by developing the transportation facilities (roads, railways and others). During the last six decades the environmental changes affect strongly on the shore line characteristics. In addition to the changes of the drainage patterns that have been established from the erosion of sedimentary plateau. The effect of these changes are studied and analyzed [13] by using different aerial photographs as multi temporal data. They recommended in their study to use multi temporal aerial photographs for any developed area in order to monitor the effect of environmental changes on drainage patterns and urban planning in that region. In such regions, protection work is needed (detention dams, diversion channel etc.) to protect residential areas.

\section{DATA ACQUiSION AND Methodolgy}

Three different aerial photograph missions (1954, 2004, and 2012) was interpreted and used with soil characteristics for the study area, collected from field investigation, laboratory analysis these photographs are shown in Fig. 2, Fig. 3 and Fig. 4 respectively.

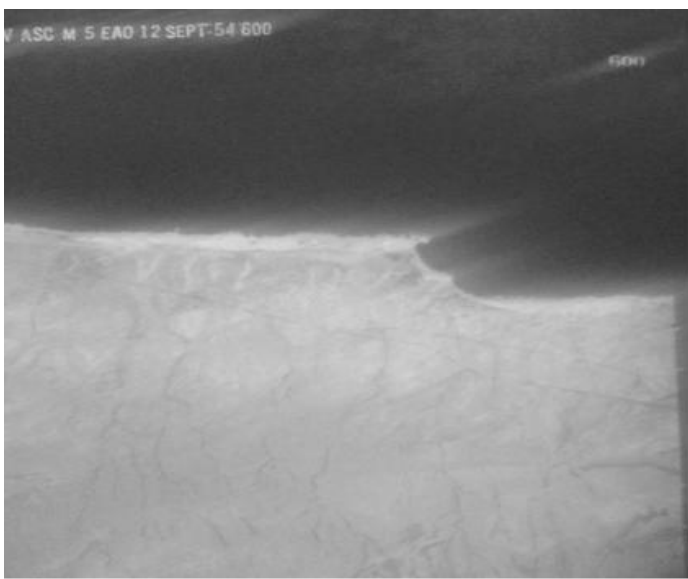

Fig. 2. Mission 1954

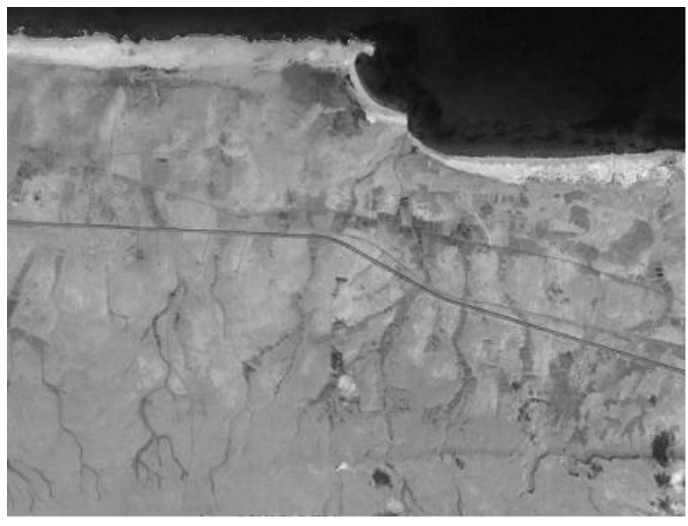

Fig. 3. Mission 2004. 


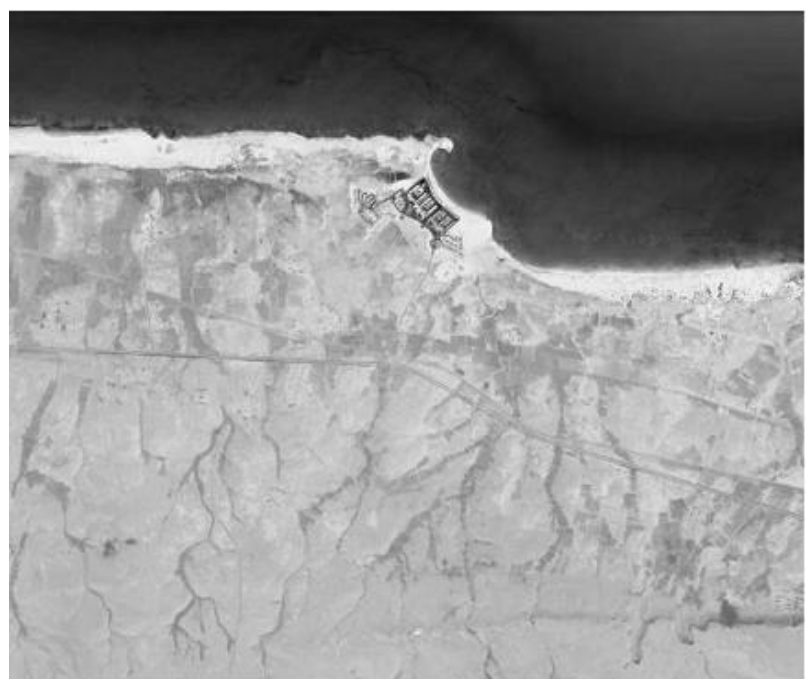

Fig. 4. Mission 2012.

TABLE I: THE THREE MisSIONS AND FILED DATA

\begin{tabular}{|c|c|c|c|c|}
\hline Data & $\begin{array}{c}\text { Mission } \\
1954\end{array}$ & $\begin{array}{l}\text { Mission } \\
2004\end{array}$ & $\begin{array}{c}\text { Mission } \\
2012\end{array}$ & $\begin{array}{c}\text { Field } \\
\text { measurements } \\
\text { (in 2012) }\end{array}$ \\
\hline $\begin{array}{c}\text { Shoreline } \\
\text { length }\end{array}$ & $13.1 \mathrm{~km}$ & $13.8 \mathrm{~km}$ & $14.5 \mathrm{~km}$ & $14.65 \mathrm{~km}$ \\
\hline area & $32.5 \mathrm{~km}^{2}$ & $32.2 \mathrm{~km}^{2}$ & $\begin{array}{l}29.5 \\
\mathrm{~km}^{2}\end{array}$ & $29.7 \mathrm{~km}^{2}$ \\
\hline $\begin{array}{l}\text { Av. Distance } \\
\text { from the } \\
\text { highway to } \\
\text { the shoreline }\end{array}$ & $1508 \mathrm{~m}$ & $1504 \mathrm{~m}$ & $1503 \mathrm{~m}$ & $1503.5 \mathrm{~m}$ \\
\hline
\end{tabular}

TABLE II: FILED MEASURMENTS AND MisSION 2012 DATA

\begin{tabular}{ccccc}
\hline \hline Data & $\begin{array}{c}\text { Mission } \\
2012\end{array}$ & $\begin{array}{c}\text { Field } \\
\text { measurements } \\
\text { (in 2012) }\end{array}$ & $\begin{array}{c}\text { Difference } \\
\text { between } \\
\text { Mission 2012 } \\
\text { and Field } \\
\text { measurements }\end{array}$ & $\begin{array}{c}\text { Error } \\
(\%)\end{array}$ \\
\hline $\begin{array}{c}\text { Shoreline } \\
\text { length } \\
\text { area } \\
\text { Av. }\end{array}$ & $14.65 \mathrm{~km}$ & $14.65 \mathrm{~km}$ & $0.15 \mathrm{~km}$ & 1.02 \\
$\begin{array}{c}\text { Distance } \\
\text { from the } \\
\text { highway } \\
\text { to the } \\
\text { shoreline }\end{array}$ & $1503.5 \mathrm{~m}$ & $1503.5 \mathrm{~m}$ & $0.5 \mathrm{~m}$ & 0.033 \\
\hline \hline
\end{tabular}

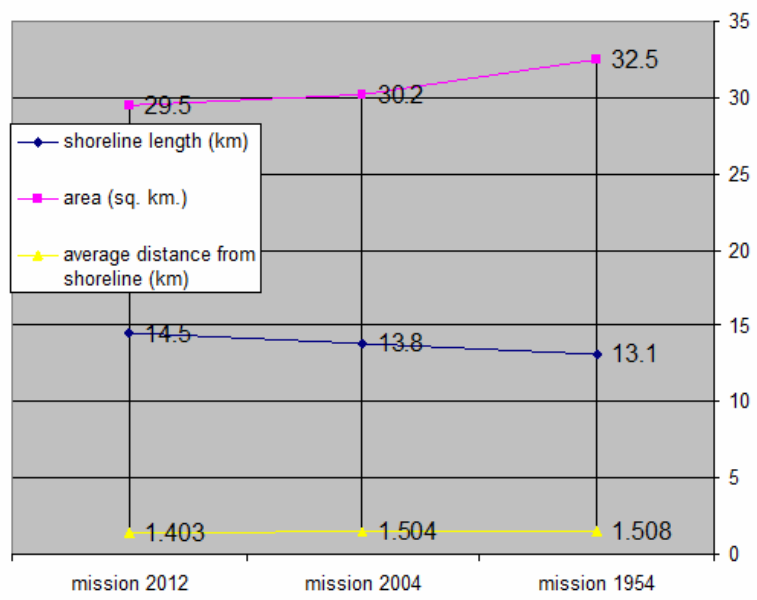

Fig. 5. Variation in each category for the three different missions.
For the three missions and the field measurements, the shore line lengths the areas bounded by the international highway and the shoreline are tabulated in Table I in addition to the average distances from the highway to the shoreline.

The stationary ground control points were selected every 0.5 kilometer along the highway, the distance from the highway to the shoreline have been measured perpendicular to avoid the disorientation of each mission during the flight line.

Table II summarized the error between the measure field data and mission 2012 while Fig. 2 illustrates the changes in each category for the three different missions.

\section{RESULTS AND ANALYSIS}

As illustrate in Table I and Fig 5 the shoreline length has been increased $0.7 \mathrm{~km}$ from 1954 to 2004 that is equivalent to $140 \mathrm{~m} / \mathrm{yr}$., while it has been increased $0.7 \mathrm{~km}$ from 2004 to 2012 that is equivalent to $87.5 \mathrm{~m} / \mathrm{yr}$.

While the shoreline erosion toward the land has been decreased $29 \mathrm{~m}$ from 1954 to 2004 that is equivalent to $8 \mathrm{~cm} /$ yr., while it has been decreased $3 \mathrm{~m}$ from 2004 to 2012 that is equivalent to $12.5 \mathrm{~cm} / \mathrm{yr}$.

It is clear from these results that the rate of erosion from 2004 to 2012 is greater than its value from 1954 to 2004; this could be related do different reasons as the raising of mean sea level and the combined effect of Vertical land motions and Non uniform thermal expansion and salinity effects associated with sea circulation changes. Also the climate change and it affects on flash floods repetitions has its direct effects on; land relief, On drainage patterns, shore line, and sea bed near the shore.

While from Table II it is clear that from comparing the extracted data from the aerial mission for year 2012 and the field measurements that the minimum error is found in average distance from the highway to the shoreline (or the shoreline degradation) because it accurate and easy processes in the filed. While measuring the shoreline length is difficult in the filed due to sea current. Also in the air born it is very difficult to identify this edge curvature and during the mission it contains significant errors.

\section{CONCLUSIONS AND RECOMENDATIONS}

This paper develops an approach to investigate how shoreline erosion could be measured from different aerial mission using stationary ground locations. When no tide gauges are available, shoreline erosion can be used to evaluate where we could focus on these regions.

This approach has been illustrated here in the three aerial missions. While indeed more investigation need to be carried out using satellite data instead of air born missions.

Beyond the significance of the results represented in this paper, we believe that the approach proposed here can be usefully extended to more details investigations in order to further study the relationship between erosion and sea level rise.

This should be helpful in urban planning, site selection of infrastructures, and appropriate selection of protection work against shoreline erosion 


\section{ACKNOWLEDGMENT}

H. M. Elhanafy thanks the Egyptian armed forces staff especially the Military Technical College staff for their scientific support and help.

\section{REFERENCES}

[1] M. L. Yates, G. L. Cozannet, M. Garcin, E. Salaï, and P. Walker, "Multidecadal Atoll shoreline change on Manihi and Manuae, French Polynesia," Journal of Coastal Research, vol. 29, iss. 4, pp. 870-882, July 2013.

[2] G. L. Cozannet, M. Garcin, L. Petitjean et al., "Exploring the relation between sea level rise and shoreline erosion using sea level reconstructions: an example in French Polynesia," Journal of Coastal Research, Special Issue, no. 65, pp. 2137-2142, March 2013.

[3] R. J. Nicholls and A. Cazenave, "Sea-Level rise and its impact on coastal zones," Science Magazine, vol. 328, pp. 1517-1520, June 2010

[4] P. Bruun, "Sea-level rise as a cause of shoreline erosion," Journal of Waterways and Harbours Division, ASCE, vol. 88, pp. 117-130, 1962.

[5] O. H. Pilkey and J. A. G. Cooper, "Society and sea level rise," Science Magazine, vol. 303, pp. 1781-1782, 2004.

[6] E. C. F. Bird, "Coastal erosion and rising sea level," in Sea Level Rise and Coastal Subsidence, J. D. Millimann and B. U. Haq, Eds. Dordrecht, the Netherlands, Kluwer Academic Publishers, pp. 87-103, 1996.

[7] A. Lombard, A. Cazenave, P. Y. L. Traon, and M. Ishii, "Contribution of thermal expansion to present-day sea-level change revisted," Journal of Global and Planetary Change, vol. 47, pp. 1-16, May 2005.

[8] A. Cazenave and W. Llovel, " Contemporary sea level rise," Annual Rev. of Marine Sciences, vol. 2, pp. 145-173, 2010.

[9] B. Meyssignac and A. Cazenave, "Sea level: A review of present-day and recent-past changes and variability," Journal of Geodynamics, vol. 58, pp. 96-109, 2012.

[10] G. Wöppelmann, B. M. Miguez, M. N. Bouin, and Z. Altamimi, "Geocentric sea-level trend estimates from GPS analyses at relevant tide gauges world-wide," Global and Planetary Change, vol. 57, pp. 396-406, June 2007.

[11] G. A. Milne, W. R. Gehrels, C. W. Hughes, and M. E. Tamisiea, "Identifying the causes of sea-level change," Journal of Nature Geoscience, vol. 2, pp. 471 - 478, June 2009.

[12] D. Stammer, A. Cazenave, A. M. Ponte, and M. E. Tamisiea, " Causes for contemporary regional sea level changes," Annual Review of Marine Science, vol. 5, pp. 21-46, January 2013.

[13] O. M. Moussa, N. H. Abdelmetaal, A. E. Elmongy, and H. M. EL-Hanfy, "Effect of environmental changes on drainage patterns and urban planning along coastal regions (Case study)," in Proc. 1999 Third International Conference On Civil \& Architecture Engineering, Military Technical College , Kobry Elkobbah, Cairo, Egypt, 1999, pp. $1-17$.

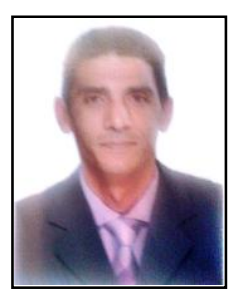

Hossam Eldin Mohammed Mohamed Elhanafy was born in Cairo, Egypt on Dec. 18, 1971. He had been conferred upon the degree of bachelor of science in civil engineering and he had been the third in general arrangement from The Military Technical College (M.T.C.) in July 1994 with the grade (Excellent with Honors). "GPA= 3.84". Then he had been conferred upon the degree of master of science in civil engineering in the field of Hydraulics on Nov. 1999 from the Military Technical College. He had been conferred upon the degree of Doctor of Philosophy in Civil engineering in the field of Hydrology on Nov. 2008 from Strathclyde Univerity, U.K.

He had been an instructor in the M.T.C. from Oct. 10, 1995 till Nov. 12, 1999, then as a teacher assistant in the civil engineering dept. at the M.T.C. from Nov. 1999 till now 2005. He worked as a teacher assistant in the civil engineering dept. at Strathclyde University from 2005 till 2008.

He teaches in different institutes in the civil engineering Department (such as Al-Obour Higher Institute for Engineering and Technology and Higher Institute of Engineering in 15 May), in addition to the Military Technical College. 